\title{
Possible Trajectories of Agricultural Cropping Systems in China from 2011 to $2050^{*}$
}

\author{
Junfang Zhao, Jianping Guo \\ Chinese Academy of Meteorological Sciences, Beijing, China \\ Email: zhaojf@cams.cma.gov.cn, gjp@cams.cma.gov.cn
}

Received March 21, 2013; revised April 26, 2013; accepted May 29, 2013

Copyright (C) 2013 Junfang Zhao, Jianping Guo. This is an open access article distributed under the Creative Commons Attribution License, which permits unrestricted use, distribution, and reproduction in any medium, provided the original work is properly cited.

\begin{abstract}
Predicting the possible impacts of future climate change on cropping systems can provide important theoretical support for reforming cropping system and adjusting the distribution of agricultural production in the future. The study was based on the daily data of future B2 climate scenario (2011-2050) and baseline climate condition (1961-1990) from high resolution regional climate model PRECIS ( $\sim 50 \mathrm{~km}$ grid interval). According to climatic divisions of cropping systems in China, the active accumulated temperature stably passing the daily average temperature of $0^{\circ} \mathrm{C}$, the extreme minimum temperature and the termination date passing the daily average temperature of $20^{\circ} \mathrm{C}$ which were justified by dominance as a limitation of different cropping systems in zero-grade zone were investigated. In addition, the possible trajectories of different cropping systems in China from 2011 to 2050 were also analyzed and assessed. Under the projected future B2 climate scenario, from 2011 to 2050, the northern boundaries of double cropping area and triple cropping area would move northward markedly. The most of the present double cropping area would be replaced by the different triple cropping patterns, while current double cropping area would shift towards areas presently dominated by single cropping systems. Thus the shift of multiple cropping areas would lead to a significant decrease of single cropping area. Compared with China's land area, the percentage cover of single cropping area and double cropping area would decrease slowly, while percentage cover of triple cropping area would gradually increase.
\end{abstract}

Keywords: Climate Change; Agriculture in China; Northern Boundary of Cropping System

\section{Introduction}

Climate change, which is largely a result of burning fossil fuels, has already affected the Earth's temperature, precipitation, and hydrological cycles. Continuous changes in the frequency and intensity of precipitation, heat waves, and other extreme events are likely, and will put increasing stresses on agricultural production [1]. Furthermore, compounded climate changes can decrease plant productivity, resulting in price increases for many important agricultural crops, especially in the developing world [1]. In China, there is a growing contradiction between rapid and continuous population growth and the associated increasing demands on agricultural products associated with continuous population growth and the limited water and land resources that will likely be intensified as consequences climate change. How the climate change affects the agriculture and cropping system has

\footnotetext{
*Supported by the China Meteorological Administration Special Climate Change Research Fund (CCSF201346), and China Meteorological Administration Special Public Welfare Research Fund (GYHY201106020).
}

attracted increasingly great attentions of scholars home and abroad [2-6].

Climate change and agriculture are interrelated processes, both of which take place on a global scale. Global warming is projected to have significant impacts on conditions affecting agriculture, including temperature, carbon dioxide, glacial run-off, precipitation and the interaction of these elements [7-9]. In general, higher $\mathrm{CO}_{2}$ concentration increases plant productivity due to higher rates of photosynthesis and increased water use efficiency $[10,11]$. Increased temperatures can reduce plant productivity through heat stress and increased water demand in some areas [3-12]. Changes in temperatures and rainfall can also change the phenological requirements of future crops $[12,13]$. The response of cropping systems to future climate change also depends strongly on management practices, such as the type and levels of water and nutrient applications. It is well-known that water limitation tends to enhance the positive crop response to elevated $\mathrm{CO}_{2}$, compared to well-watered conditions [14, 15]. The contrary is true for nitrogen limitation: well- 
fertilised crops respond more positively to $\mathrm{CO}_{2}$ than less fertilised ones $[16,17]$. Therefore, a wide range adaptation of cropping systems to climate change may exist in order to maintain or even increase crop yields under future climate change compared to current conditions.

Studies on the responses of cropping systems to climate change in China have been highlighted and made great progress $[6,8,18-20]$. Wang [18] simulated the potential impacts of climate change on cropping systems in China based on the regional climate change scenario for China estimated by composite GCM and found that the northern boundary of triple cropping area would shift from its current border at the Changjiang River to the Huanghe River, a shift of more than 5 degrees of latitude in the year 2050, while the current double cropping area would shift towards the central part of the present single cropping area. Zhang [19] analyzed the response of cropping systems to climate change, and pointed out the northern boundary of triple cropping area and double cropping area would move northwardly, and the cropping range, output and quality of crops would be changed in future. Yang et al. [6] analyzed the possible effects of climate warming on the countrywide northern limits of cropping systems, the northern limits of winter wheat and double rice, and the stable-yield northern limits of rainfed winter wheat-summer maize rotation in China from 1981 to 2007 , and drew a conclusion that during the past 50 years, the climate warming caused the northwards movement of the northern limits of cropping system, and the northern limits of winter wheat and double rice. The changes might increase the unit grain yield in the changing area. However, the stable-yield northern limits of rainfed winter wheat-summer maize rotation moved southeastwards due to the decreasing rainfall. These results will contribute to better planning of resources, productivity and environmental sustainability. However, because of the complicated Chinese farming patterns, the complex social and economic environment of agricultural development and, especially, great scientific uncertainties in the prediction of climate change [21], and differences in the climate scenarios produced by different global climate models [22-24], accurately predicting the impacts of climate change on cropping systems in China is still an critical and unsolved issue in scientific community, either quantitatively or qualitatively.

The objectives of this work were: 1) to investigate the active accumulated temperature stably passing the daily average temperature of $0^{\circ} \mathrm{C}$, the extreme minimum temperature and the termination date passing the daily average temperature of $20^{\circ} \mathrm{C}$ which are justified by dominance as a limitation of different cropping systems; 2) to find out the possible changes of different cropping systems in zero-grade zone of China from 2011 to 2050; 3) to get better understanding on the potential implications of climate change for the agricultural sustainability in China.

\section{Materials and Methods}

\subsection{Data}

Daily climate variables (maximal and minimal air temperature, average air temperature, precipitation, solar radiation, relative humidity, and wind speed) from regional climate model PRECIS were provided by the Chinese Academy of Agricultural Sciences for time series of 40 and 30 years from 2011 to 2050 and from 1961 to 1990 , respectively.

\subsection{Climate Change Scenarios Selection for China}

In order to estimate the impact of greenhouse gases on global climate and socio-economy, the Intergovernmental Panel on Climate Change (IPCC) developed the emission scenarios of global greenhouse gas (SRES scenarios) in the next 100 years based on analyzing a large number of models [25]. The four SRES scenarios represent different world futures, which describe the ways in which global population, economies and non-climate policies may evolve over the coming decades. Even though the scenarios include a multidimensional space and no simple metric can be used to classify them it has been useful to describe the scenarios using two dimensional spaces. The first dimension designates a more economic (A) or a more environmental (B) orientation and the second dimension a more global (1) or a more regional (2) orientation. Accordingly, the scenarios are termed as A1, A2, $\mathrm{B} 1$, and $\mathrm{B} 2$.

In this study, regional climate scenarios were generated using a relatively high resolution ( $\sim 50 \mathrm{~km}$ grid size $)$ atmospheric regional model (PRECIS-Providing Regional Climates for Impacts Studies, [26-28]). The data of future B2 scenario from PRECIS model outputs, which fitted broadly with China's national social and economic development plans over the medium to long term, were selected in this study. According to PRECIS scenario output, air temperature and precipitation in 2050s would increase by $2.4^{\circ} \mathrm{C}$ and $6 \%$, respectively, compared to a baseline period (1961-1990) under future B2 climate scenario.

\subsection{Indices for Agricultural Cropping System}

Indices for agricultural cropping system were based on existing climatic divisions of cropping systems in China (Table 1). According to climatic divisions of cropping systems in China, the cropping systems in zero-grade zone were divided by the heat, while the cropping systems in first zone and secondary zone were divided by 
Table 1. Indices for the zero-grade zone in climatic divisions of cropping systems in China.

\begin{tabular}{cccc}
\hline $\begin{array}{c}\text { Accumulated } \\
\text { propping } \\
\text { patterns } \\
\text { temperature stably } \\
\text { passing the daily } \\
\text { average temperature } \\
\text { of } 0^{\circ} \mathrm{C}\left({ }^{\circ} \mathrm{C} \cdot \mathrm{d}\right)\end{array}$ & $\begin{array}{c}\text { Extreme } \\
\text { minimum } \\
\text { temperature } \\
\left(0^{\circ} \mathrm{C}\right)\end{array}$ & $\begin{array}{c}\text { Termination date } \\
\text { stably passing the } \\
\text { daily average } \\
\text { temperature of } 20^{\circ} \mathrm{C}\end{array}$ \\
\hline $\begin{array}{c}\text { Single } \\
\text { cropping } \\
\text { area }\end{array}$ & $>4000-4200$ & $<-20$ & $\begin{array}{c}\text { Early August-Early } \\
\text { September }\end{array}$ \\
$\begin{array}{c}\text { Double } \\
\text { cropping } \\
\text { area }\end{array}$ & $>4000-4200$ & $<-20$ & $\begin{array}{c}\text { Early September- } \\
\text { Beginning in late } \\
\text { Sriple }\end{array}$ \\
$\begin{array}{c}\text { September } \\
\text { cropping } \\
\text { area }\end{array}$ & $>5900-6100$ & $>-20$ & $\begin{array}{c}\text { Beginning in late } \\
\text { September-Early } \\
\text { November }\end{array}$ \\
\hline
\end{tabular}

heat, moisture, topography and plant [6]. This study was mainly focused on the changes of different cropping systems in zero-grade zone caused by climate change. The indices largely were determined by dominance of the active accumulated temperature stably passing the daily average temperature of $0^{\circ} \mathrm{C}$, the extreme minimum temperature and the termination date passing the daily average temperature of $20^{\circ} \mathrm{C}$ as a limitation of different cropping patterns.

The 5-day gliding average method was used to determinate the initial and final dates of stably passing certain threshold temperature [29].

\section{Results}

\subsection{Northern Boundaries of Cropping Systems under Baseline Period}

The main cropping patterns were defined by the number of different crops that grew successively and successfully during a single growing season. In order to illustrate present distribution and possible change of northern boundary of cropping system in future, here we used cropping system rather than individual crop variety as an integrated unit. According to climatic divisions of cropping systems in China, the major Chinese cropping patterns in zero-grade zone were determined with active accumulated air temperature stably passing the daily average temperature of $0^{\circ} \mathrm{C}$, the extreme minimal air temperature and the termination date passing the daily mean air temperature of $20^{\circ} \mathrm{C}$ (see Table 1).

The results illustrated that the distributions of northern boundaries of double and triple cropping systems in China under baseline period (Figure 1).

The active accumulated temperature values of $4000^{\circ} \mathrm{C}$ and $5900^{\circ} \mathrm{C}$ stably passing the daily average temperature of $0^{\circ} \mathrm{C}$ were significant in distinguishing between the single-double and double-triple cropping systems respectively. The vast western area was dominated by single cropping pattern owing to lower temperature and earlier termination date stably passing the daily average temperature of $20^{\circ} \mathrm{C}$. Generally speaking, this simulated map was well fitted with the actual distribution of cropping patterns in China and relevant findings from other researches [18].

\subsection{Potential Changes of Northern Boundaries of Cropping Pattern}

There were potential changes of northern boundaries of double and triple cropping areas projected by the regional climate model PRECIS every 10 years from 2011 to 2050 , respectively, compared to the baseline period (1961-1990) (Figures 2 and 3).

Great changes might occur almost everywhere in China except for the high altitude Qinghai-Xizang Plateau in southwestern China and the northern most part of Northeast China. The northern boundaries of double and triple cropping areas might shift northward in different degrees with the increased accumulated temperature from 2011 to 2050. For the northern boundary of double cropping areas, the larger spatial displacement might occur over provinces of Shannxi, Shanxi, Hebei, Beijing, Liaoning, Jilin, Gansu and Sichuan (Figure 2).

Especially, the average moving distance of northern boundary in Shaanxi, Shanxi and Hebei Province would be about $220 \mathrm{~km}$ during the 2041-2050, and the northern boundary in south of Liaoning Province might shift from the $38^{\circ} 43^{\prime} \mathrm{N}$ to $46^{\circ} 8^{\prime} \mathrm{N}$ in Jilin Province. For the northern boundary of triple cropping areas, the larger spatial displacement might occur in provinces of Sichuan, Yunnan, Hunan, Hubei, Anhui, Guizhou, Zhejiang, Chongqing, and Jiangsu Province (Figure 3). For example, the northern boundary might shift from $27^{\circ} 24^{\prime} \mathrm{N}$ in Zhejiang Province (1961-1990) to $33^{\circ} 26^{\prime} \mathrm{N}$ in Jiangsu Province (2041-2050), and the average moving distance of northern boundary in Hubei Province would be $229 \mathrm{~km}$. The results showed that the fractional cover of multiple cropping areas to China's land area might change significantly under B2 climate scenarios without changing the variety and level of future production (Figure 4). Compared with China's land area, the percentage cover of single cropping area and double cropping area to China's land area would decrease slowly, while the percentage cover of triple cropping area would gradually increase. The percentage cover of single cropping area was $71.7 \%$ in 1961-1990, but would likely change to $69.8 \%$ in $2011-2020,69.6 \%$ in $2021-2030,68.4 \%$ in $2031-2040$, and $66.6 \%$ in $2041-2050$, respectively. The percentage covers of double cropping area were 17.6\% (1961-1990), $16.3 \%$ (2011-2020), 15.4\% (2021-2030), $12.8 \%$ (2031-2040), and 13.3\% (2041-2050), respectively. The percentage covers of triple cropping area were $10.6 \%$ (1961-1990), 13.9\% (2011-2020), 15.0\% (2021-2030), $18.8 \%(2031-2040)$, and $20.1 \%(2041-2050)$, respec- 


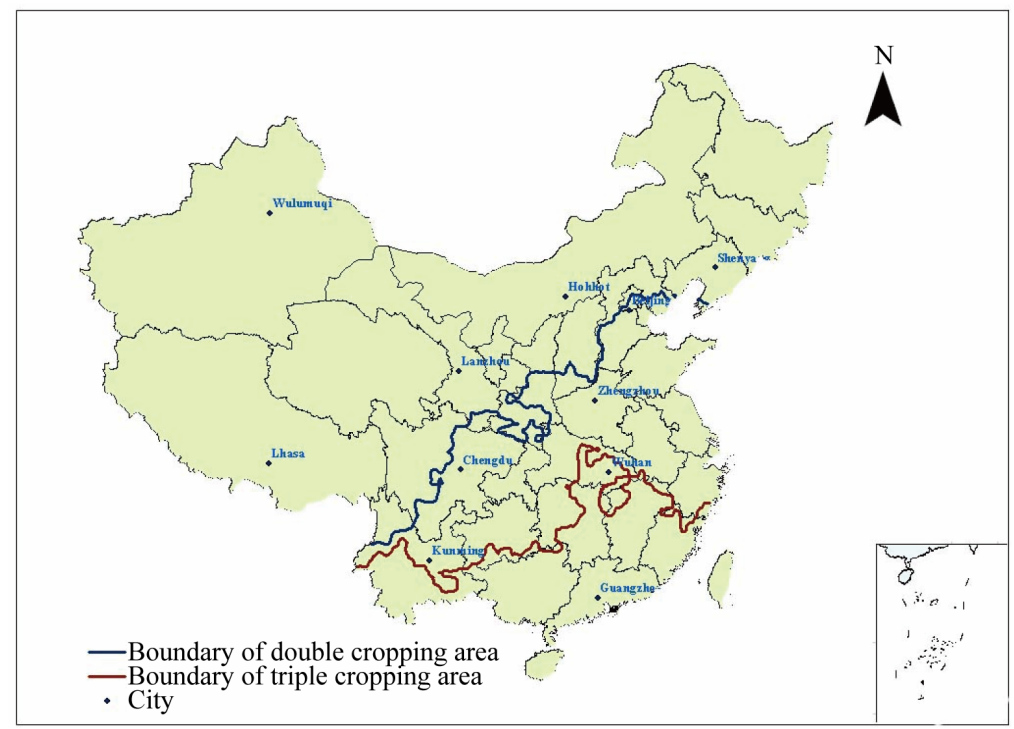

Figure 1. The average northern boundaries of double and triple cropping areas from 1961 to 1990 under future B2 climate change.

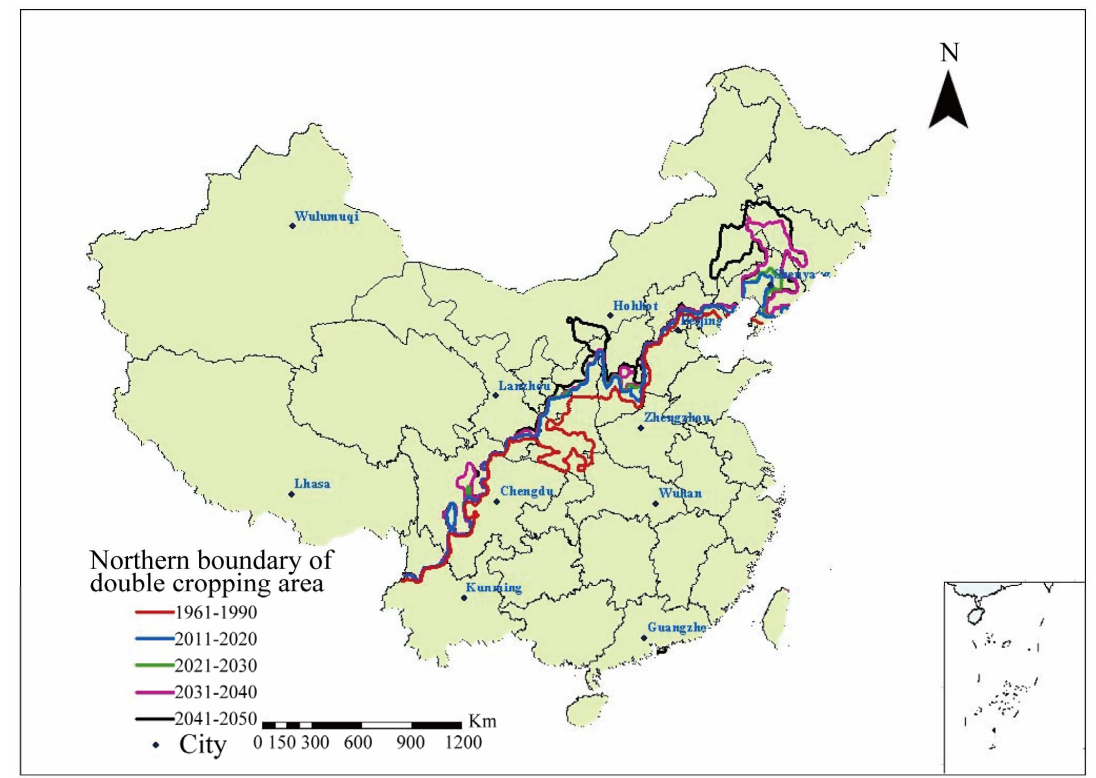

Figure 2. The possible changes of northern boundaries of double cropping areas every ten years from 2011 to 2050 under future B2 climate change compared to baseline period (1961-1990).

tively.

\section{Conclusions and Discussion}

Possible trajectories of different cropping systems in China from 2011 to 2050 were simulated and assessed based on the daily data of future B2 climate scenario (2011-2050) and baseline period (1961-1990) from regional climate model PRECIS at spatial resolution of 50 $\mathrm{km} \times 50 \mathrm{~km}$. Our study indicated that major changes would occur almost everywhere in China except for the Qinghai-Xizang Plateau in southwestern China and the northern most part of Northeast China. Under the projected future B2 climate scenario, from 2011 to 2050, the northern boundaries of double cropping area and triple cropping area would move northward markedly. For the northern boundaries of double cropping areas, great spatial displacement might occur in provinces such as Shannxi, Shanxi, Hebei, Beijing, Liaoning, Jilin, Gansu and Sichuan. For the northern boundaries of triple cropping areas, major spatial displacement might occur in provinces of Sichuan, Yunnan, Hunan, Hubei, Anhui, Guizhou, Zhejiang, Chongqing, and Jiangsu. The most parts of the present double cropping area would be re- 


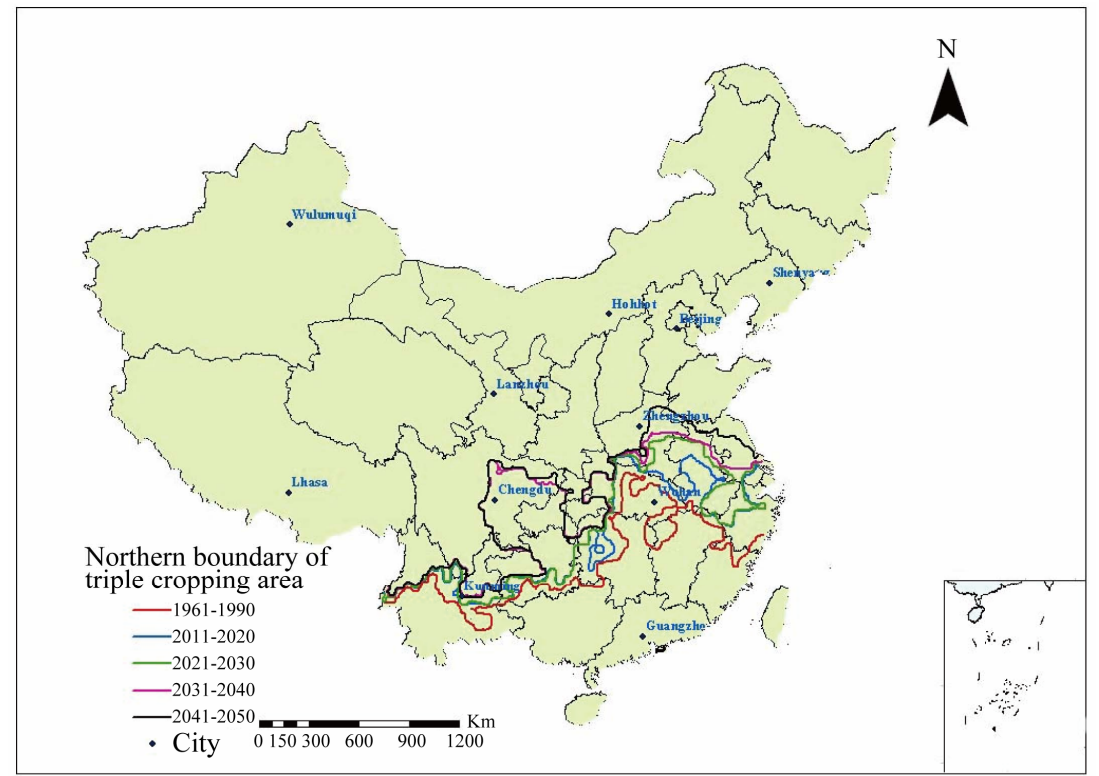

Figure 3. The possible changes of northern boundaries of triple cropping areas every ten years from 2011 to 2050 under future B2 climate change compared to baseline period (1961-1990).

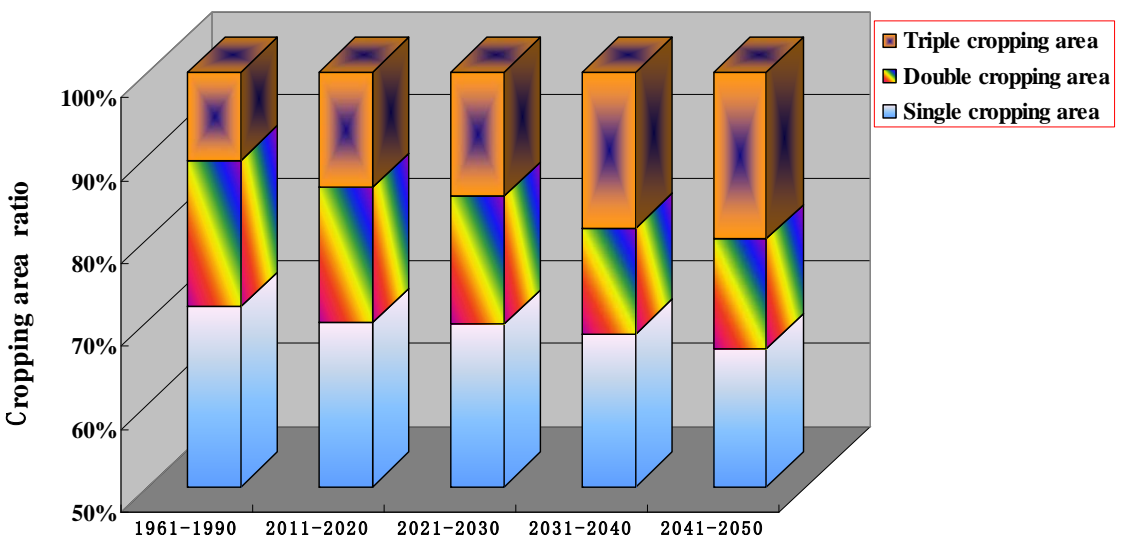

Figure 4. The percentage covers of single, double and triple cropping areas to China's land area under future B2 climate change.

placed by triple cropping systems, while the current double cropping area would shift towards the present single cropping area. Thus the shift of multiple cropping areas would lead to a significant decrease of single cropping area. The percentage covers of single cropping area to China's land area were $71.7 \%$ in $1961-1990$, but will likely change to $69.8 \%$ in $2011-2020,69.6 \%$ in 2021 $2030,68.4 \%$ in $2031-2040$, and $66.6 \%$ in $2041-2050$, respectively. The percentage covers of double cropping area to China's land area were $17.6 \%(1961-1990)$, $16.3 \%$ (2011-2020), 15.4\% (2021-2030), 12.8\% (20312040), and $13.3 \%$ (2041-2050), respectively. The percentage covers of triple cropping area to China's land area were $10.6 \%(1961-1990), 13.9 \% \quad(2011-2020)$, $15.0 \%$ (2021-2030), $18.8 \%$ (2031-2040), and $20.1 \%$ (2041-2050), respectively. In summary, this study pro- vides further evidence for reforming cropping system and making decision of agricultural sustainable development planning in China under climate change. The exact dynamics of these changes require further investigation with both modeling and field-based studies.

This study mainly focuses on the possible impacts of climate change on northern boundaries of cropping systems in zero-grade zone of China, which provides a scientific basis for the cropping system's change. The results of this study are supported by the recent reports $[6,18]$. However, there is a discrepancy between our result and the conclusion of Zhang [19] that she figured out the ratio of single cropping area would decrease, while the ratios of double and triple cropping areas would gradually increase. The possible reason for this difference is Zhang used the national cultivated area instead of 
land area. However, with expansion of population and improvement in living standard, there is an increase in demand for grains in Mainland China; in contrast the area of cultivated lands tends to decrease with time [4].

But whether the potential changes in cropping systems induced by climate warming can become a reality is largely determined by factors such as water, economic benefits, and social benefits etc. Take the precipitation which is one of main climatic factors limiting agricultural production in northern China as an example; multiple cropping planting will require more water, which is incompatible between water supply and demand. In theory, the northern boundary of double cropping area will move northward significantly, that is to say the northern boundary of winter wheat will move northward drastically. However, the climate in the northern China is characterized by scarce rainfall in autumn and spring, and vast amount of water that winter wheat required for normal growth must rely on irrigation from groundwater, which will lead to declining of water table, and further affecting water use of harvest crops in autumn. Therefore, moving northward of multiple cropping systems is not simple issue and still should be cautious.

In this paper, we try to use the indices of cropping systems in zero-grade zone of China from previous research results [6] because it's better performance in comparison with other methods. However, new indicators for agricultural cropping system nationwide under climate change are notoriously difficult to get. Uncertainties may be involved in estimating the impacts of future climate change on cropping systems. Therefore, in order to get a more precise estimation, it is necessary to carry out more detailed studies, and to further adjust indices of cropping systems. In addition, our study is mainly focused on the changes of different cropping systems in zero-grade zone divided by the heat under climate change. Restrictions of variety characteristics, water levels, economic conditions etc. are not sufficiently considered. Large uncertainties on the boundaries of the predictions exist. Differences in the daily characteristics of climate variables and differences between ensemble experiments will also affect the overall results. None the less, there is a broad agreement that, in addition to increased temperature, climate change will bring about regionally dependent increase or decrease in rainfall, an increase in cloud cover and increases in sea level. Extreme weather events will also increase in intensity or frequency, such as higher maximum temperatures, more intense precipitation events, increased risk and duration of drought, and increased peak wind intensities of cyclones [30-33]. However, climate models, either global or regional, are unlikely to capture fully the spatial and temporal detail of many extreme events across China. This is due to the imperfect understanding of their physical causes and limitations related to model structure. Thus the impacts of climate fluctuations and extremes on changes in cropping systems are not taken into account in this paper.

\section{REFERENCES}

[1] IPCC, "Climate Change 2007: The Physical Science Basis, Summary for Policy Makers," IPCC WGI 4th Assessment Report, Paris, 2007.

[2] M. Cao, S. Ma and C. Han, "Potential Productivity and Human Carrying Capacity of an Agro-Ecosystem: An Analysis of Food Production Potential of China," Agricultural Systems, Vol. 47, No. 4, 1995, pp. 387-414. doi:10.1016/0308-521X(95)92106-G

[3] F. L. Tao, M. Yokozawa, Y. Hayashi and E. D. Lin, "Changes in Agricultural Water Demands and Soil Moisture in China over the Last Half-Century and Their Effects on Agricultural Production," Agricultural and Forest Meteorology, Vol. 118, No. 3-4, 2003, pp. 251-261. doi:10.1016/S0168-1923(03)00107-2

[4] J. K. Zhang, F. R. Zhang, D. Zhang, D. X. He, L. Zhang, C. G. Wu and X. B. Kong, "The Grain Potential of Cultivated Lands in Mainland China in 2004," Land Use Policy, Vol. 26, No. 1, 2008, pp. 68-76. doi:10.1016/j.landusepol.2008.01.002

[5] W. Xiong, D. Conway, E. D. Lin, Y. L. Xu, H. Ju, J. H. Jiang, I. Holman and Y. Li, "Future Cereal Production in China: The Interaction of Climate Change, Water Availability and Socio-Economic Scenarios," IOP Conference Series: Earth and Environmental Science, Vol. 6, 2009, pp. 34-44. doi:10.1088/1755-1307/6/7/372004

[6] X. G Yang, Z. J. Liu and F. Chen, "The Possible Effects of Global Warming on Cropping Systems in China I. The Possible Effects of Climate Warming on Northern Limits of Cropping Systems and Crop Yields in China," Scientia Agricultura Sinica, Vol. 43, No. 2, 2010, pp. 329-336. doi:10.1016/S1671-2927(11)60040-0

[7] C. Rosenzweig and D. Hillel, "Climate Change and the Global Harvest," Oxford University Press, Oxford, 1998.

[8] N. T. Francesco, D. Marcello, C. Rosenzweig and O. S. Claudio, "Effects of Climate Change and Elevated $\mathrm{CO}_{2}$ on Cropping Systems: Model Predictions at Two Italian Locations," European Journal of Agronomy, Vol. 13, No. 2-3, 2000, pp. 179-189.

[9] S. D. Gryze, A. Wolf, S. R. Kaffka, J. Mitchell, D. E. Rolston, S. R. Temple, J. Lee and J. Six, "Simulating Greenhouse Gas Budgets of four California Cropping Systems under Conventional and Alternative Management," Ecological Applications, Vol. 20, No. 7, 2010, pp. 1805-1819. doi:10.1890/09-0772.1

[10] F. Ewert, D. Rodriguez, P. Jamieson, M. A. Semenov, R. A. C. Mitchell, J. Goudriaan, J. R. Porter, B. A. Kimball, P. J. Pinter, R. Manderscheid, H. J. Weigel, A. Fangmeie, E. Fereres and F. Villalobos, "Effects of Elevated $\mathrm{CO}_{2}$ and Drought on Wheat: Testing Crop Simulation Models for Different Experimental and Climatic Conditions," Agriculture, Ecosystems \& Environment, Vol. 93, No. 1-3, 2002, pp. 249-266. doi:10.1016/S0167-8809(01)00352-8 
[11] P. J. Gregory, S. N. Johnson, A. C. Newton and J. S. I. Ingram, "Integrating Pests and Pathogens into the Climate Change/Food Security Debate," Journal of Experimental Botany, Vol. 60, No. 10, 2009, pp. 2827-2838. doi:10.1093/jxb/erp080

[12] D. W. Lawlor and R. A. C. Mitchell, "Crop Ecosystem Responses to Climatic Change: Wheat. Climate Change and Global Crop Productivity," CAB International, Cambridge, 2000, pp. 57-80. doi: $10.1079 / 9780851994390.0057$

[13] F. N. Tubiello, M. Donatelli, C. Rosenzweig and C. O. Stockle, "Effects of Climate Change and Elevated $\mathrm{CO}_{2}$ on Cropping Systems: Model Predictions at Two Italian Locations," European Journal of Agronomy, Vol. 13, No. 2-3, 2000, pp. 179-189. doi:10.1016/S1161-0301(00)00073-3

[14] U. N. Chaudhuri, M. B. Kirkam and E. T. Kanemasu, "Root Growth of Winter Wheat under Elevated Carbon Dioxide and Drought," Crop Science, Vol. 30, No. 4, 1990, pp. 853-857. doi:10.2135/cropsci1990.0011183X003000040017x

[15] B. A. Kimball, P. J. J. Pinter, R. L. Garcia, R. L. LaMorte, G. W. Wall, D. J. Hunsaker, G. Wechsung, F. Wechsung and T. Kartschall, "Productivity and Water Use of Wheat under Free-Air $\mathrm{CO}_{2}$ Enrichment," Global Change Biology, Vol. 1, No. 6, 1995, pp. 429-442. doi:10.1111/j.1365-2486.1995.tb00041.x

[16] N. Sionit, D. A. Mortensen, B. R. Strain and H. Hellmers, "Growth Response of Wheat to $\mathrm{CO}_{2}$ Enrichment and Different Levels of Mineral Nutrition," Agronomy Journal, Vol. 73, No. 6, 1981, pp. 1023-1027.

[17] R. A. C. Mitchell, V. J. Mitchell, S. P. Driscoll, J. Franklin and D. W. Lawlor, "Effects of Increased $\mathrm{CO}_{2}$ Concentration and Temperature on Growth and Yield of Winter Wheat at Two Levels of Nitrogen Application," Plant, Cell \& Environment, Vol. 16, No. 5, 1993, pp. 521-529.

[18] F. T, Wang, "Impact of Climate Change on Cropping System and Its Implication for Agriculture in China," Acta Meteorological Sinica, Vol. 11, No. 4, 1997, pp. 407-415.

[19] H. X. Zhang, "The Response of China's Cropping Systems to Global Climatic Changes I. The Effect of Climatic Changes on Cropping Systems in China," Chinese Journal of Agrometeorology, Vol. 21, No. 1, 2000, pp. 9-13.

[20] T. Axel, "Agricultural Irrigation Demand under Present and Future Climate Scenarios in China," Global and Planetary Change, Vol. 60, No. 3-4, 2008, pp. 306-326.

[21] J. Gupta, X. Olsthoorn and E. Rotenberg, "The Role of Scientific Uncertainty in Compliance with the Kyoto Protocol to the Climate Change Convention," Environmental Science \& Policy, Vol. 6, No. 6, 2003, pp. 475-486. doi:10.1016/j.envsci.2003.09.001

[22] W. E. Easterling, L. O. Mearns, C. J. Hays and D. Marx, "Comparison of Agricultural Impacts of Climate Change Calculated from High and Low Resolution Climate Change Scenarios: Part II. Accounting from Adaptation and $\mathrm{CO}_{2}$ Direct Effects," Climate Change, Vol. 51, No. 2,
2001, pp. 173-197.

[23] F. N. Tubiello, C. Rosenzweig, R. A. Goldberg, S. Jagtap and J. W. Jones, "Effects of Climate Change on US Crop Production: Simulation Results Using Two Different GCM Scenarios. Part I: Wheat, Potato, Maize and Citrus," Climate Research, Vol. 20, No. 3, 2002, pp. 259-270. doi: $10.3354 / \mathrm{cr} 020259$

[24] E. A. Tsvetsinskaya, L. O. Mearns, T. Mavromatis, W. Gao, L. McDaniel and M. W. Downton, "The Effect of Spatial Scale of Climatic Change Scenarios on Simulated Maize, Winter Wheat and Rice Production in the Southern United States," Climate Change, Vol. 60, No. 1-2, 2003, pp. 37-72.

[25] N. Nakićenović, J. Alcamo, G. Davis, B. de Vries, J. Fenhann, S. Gaffin, K. Gregory, A. Grubler, T. Y. Jung, T. Kram, E. Emilio la Rovere, L. Michaelis, S. Mori, T. Morita, W. Pepper, H. Pitcher, L. Price, K. Riahi, A. Roehrl, H.-H. Rogner, A. Sankovski, M. E. Schlesinger, P. R. Shukla, S. Smith, R. J. Swart, S. van Rooyen, N. Victor and Z. Dadi, "Special Report on Emissions Scenarios," Cambridge University Press, Cambridge, 2000.

[26] R. G. Jones, M. Noguer, D. C. Hassell, D. Hudson, S. S. Wilson, G. J. Jenkins and J. F. B. Mitchell, "Generating High Resolution Climate Change Scenarios using PRECIS," Met Office Hadley Centre, Exeter, 2004, p. 35.

[27] Y. L. Xu, "Setting up PRECIS over China to Develop Regional SRES Climate Change Scenarios," Proceedings of the International Workshop: Prediction of Food Production Variation in East Asia under Global Warming, Tsukuba, 2004, pp. 17-21.

[28] Y. L. Xu, X. Y. Huang, Y. Zhang, Z. P. Wen and W. B. Li, "Validating PRECIS' Capacity of Simulating Present Climate over South China," Acta Scientiarum Naturalium Unversitatis Sunyatseni, Vol. 46, No. 5, 2007, pp. 93-97.

[29] J. F. Zhao, J. P. Guo, Y. P. Ma, Y. H. E, P. J. Wang and D. R. Wu, "Change Trends of China Agricultural Thermal Resources under Climate Change and Related Adaptation Countermeasures," Chinese Journal of Applied Ecology, Vol. 21, No. 11, 2010, pp. 2922-2930.

[30] J. A. Dracup, K. S. Lee and E. G. Paulson, "On the Definition of Droughts," Water Resources Research, Vol. 16, No. 2, 1980, pp. 297-302. doi:10.1029/WR016i002p00297

[31] M. Lal, K. K. Singh, L. S. Rathore, G. Srinivasan and S. A. Saseendran, "Vulnerability of Rice and Wheat Yields in NW India to Future Change in Climate," Agriculture, Ecosystems and Environment, Vol. 89, No. 2, 1998, pp. 101-114. doi:10.1016/S0168-1923(97)00064-6

[32] J. Q. Zhang, "Risk Assessment of Drought Disaster in the Maize-Growing Region of Songliao Plain, China," Agriculture, Ecosystems and Environment, Vol. 102, No. 2, 2004, pp. 133-153. doi:10.1016/j.agee.2003.08.003

[33] L. Y. Zhong, L. M. Liu and Y. B. Liu, "Natural Disaster Risk Assessment of Grain Production in Dongting Lake Area, China," Agriculture and Agricultural Science Procedia, Vol. 1, 2010, pp. 24-32. doi:10.1016/j.aaspro.2010.09.004 